\title{
Economics
}

The Open-Access, Open-Assessment E-Journal

Vol. 14, 2020-6 | February 12, 2020 | http://dx.doi.org/10.5018/economics-ejournal.ja.2020-6

\section{Public investment and economic activity in Mexico, 1925-1981}

\author{
Felipe de Jesús Fonseca, Manuel Gómez-Zaldívar, \\ and Daniel Ventosa-Santaulària
}

\begin{abstract}
The authors construct a historical database of public investment (both total and broken down into its main components) for the period 1925 to 1981 in order to measure its impact on economic activity. Given the possible presence of crowding-out effects between public investment and private investment, in their analysis they control for the latter. The results suggest that: i) public investment had a significant impact on output, one which varies depending on the category of public investment considered, and; ii) private and public investment are positively related, i.e., public investment has a crowding-in effect on private investment, and both have a positive and significant impact on GDP. The results contrast with those of previous studies that have analyzed this relationship, though using a different time period, one that includes the economic liberalization era. Nevertheless, these differences can be rationalized by the findings of Ilzetzki et al. (How Big (Small?) are Fiscal Multipliers? 2013), who point out that key country-specific characteristics such as trade openness and the exchange rate regime are determinant in the relationship between public investment and output.
\end{abstract}

JEL N16 H54 C32

Keywords Economic activity; federal public investment; long-term equilibrium relationship

\section{Authors}

Felipe de Jesús Fonseca, Bank of Mexico, Guadalajara, Mexico Manuel Gómez-Zaldívar, University of Guanajuato, Guanajuato, Mexico Daniel Ventosa-Santaulària, Centro de Investigación y Docencia Económicas (CIDE) and Bank of Mexico, Mexico City, Mexico, daniel.ventosa@cide.edu

Citation Felipe de Jesús Fonseca, Manuel Gómez-Zaldívar, and Daniel VentosaSantaulària (2020). Public investment and economic activity in Mexico, 1925-1981. Economics: The Open-Access, Open-Assessment E-Journal, 14 (2020-6): 1-24. http://dx.doi.org/10.5018/economics-ejournal.ja.2020-6

Received January 17, 2019 Published as Economics Discussion Paper March 6, 2019 Revised December 10, 2019 Accepted January 21, 2020 Published February 12, 2020

(c) Author(s) 2020. Licensed under the Creative Commons License - Attribution 4.0 International (CC BY 4.0) 


\section{Introduction}

Mexican economic historiography recognizes the key role that public investment played in the country's economic performance from the end of its Revolutionary War until the beginning of the economic liberalization period that began in the early 1980s. However, there is no concrete empirical evidence to support this assertion. ${ }^{1}$ According to Mexico's National Institute of Statistics and Geography (INEGI), between 1925 and 1981 [i.e., prior to the exhaustion of the import-substitution [IS] model), the Mexican economy grew at an average annual rate of 5.0 percent in real terms. The economic literature also acknowledges and attributes a central role to public investment in the attainment of the high growth rates observed from the postrevolutionary period up until the early 1980s, the eve of the period of economic liberalization. ${ }^{2}$ In Mexico as in other Latin American countries, public investment is considered to be the driving force behind the IS development strategy, not only due to its contribution to the increase in capital stock but also due to its being an important component of the aggregate demand that fostered the growth of major sectors of the economy.

According to the economic literature, there are two main ways in which public investment impacts growth: on the one hand, through the spillover effects that this type of investment generates once these projects are complete (Barro, 1990), and on the other, through the complementary effect public investment has on private investment, since positive externalities are generated that make the latter more efficient (Munnell, 1992).

The aim of this study is to provide empirical evidence of the importance of public investment during the years 1925-1981 and thus enable us to confirm whether the assertion that its role was significant is justified. To do this, we construct a database of public investment for the period in question. To the best of our knowledge, our study constitutes the first attempt to measure the impact of public investment on economic activity that focuses solely on the period prior to the process of economic openness experienced by the Mexican economy. Furthermore, as has been done in previous studies, we quantify the effect that public investment had on private investment during this period. ${ }^{3}$

Previous studies that have analyzed the impact of public investment on economic activity in Mexico have used data from 1950 onwards and included the period following the opening-up of trade, such as: Feltenstein and Ha (1995), the period 1970-1990; Ramírez (1996), who looks at

\footnotetext{
1 Lachler and Aschauer (1998) state that “Mexico’s growth rate began to plummet roughly at the same time that its public investment level declined. That decline also coincided with a slowdown in the growth of infrastructure capital in the electric, transport and communications sectors [...]. Many economists have attributed at least part of the blame for the decline in Mexico's growth after 1981 to the decline of public infrastructure investment." Similar arguments can be found in Ramirez (1994), Ramirez (1996) and Ramirez and Nazmi (2003).

2 See Solís (1999) and Cárdenas (1994, 2015), Ramirez (1994), Ramirez (1996), Nazmi and Ramirez (1997) among others.

3 Our sample period begins 25 years before the start year of other studies on Mexico. We do this because we do not want to employ data from after 1982 (the economic literature recognizes that Mexico's development strategy changed around that time, hence the relationship among the variables we study may be different in these two periods). To take advantage of the asymptotic properties of the time-series methods employed (the longer the series employed, the more reliable the estimations) without mixing data from two periods in which the relationship between the variables may differ, we extend our dataset as far back as possible.
} 
the period from 1950 to 1991; Nazmi and Ramírez (1997), the period 1950-1990; Lachler and Aschauer (1998), the period 1970-1996, and Noriega and Fontenla (2007), the period 19502003. Unlike these studies, ours focuses exclusively on the period prior to the opening-up of trade and extends backwards to include the maximum amount of available data. ${ }^{4}$ At the international level, Ramirez and Nazmi (2003) study the relationship between public investment and economic growth in nine Latin American countries (Argentina, Bolivia, Brazil, Chile, Colombia, Ecuador, Mexico, Peru, and Uruguay) during the period 1983-1993, and their findings suggest that public investment contributed to economic growth in all of them. Demetriades and Mamuneas (2000) study the returns on public capital in 12 OECD countries and estimate a system of equations derived from an intertemporal profit-maximization problem. Their findings suggest that public infrastructure capital has significant positive effects on profit, demand for private inputs, and the supply of output in all of the countries considered. Based on data on OECD economies, Fournier (2016) also finds evidence of a positive effect of public investment on long-term growth and on labor productivity. Evidence of the positive relationship between public investment and growth in developed countries is readily available. ${ }^{5}$

Another contribution of our study is that our database breaks down total public investment into five components, unlike the studies mentioned previously, which only consider public investment as a whole. ${ }^{6}$ Therefore, we not only estimate the impact on Gross Domestic Product (GDP) of total public investment but also classify its various components according to their importance, i.e., those that have the greatest impact on economic growth.

Furthermore, and from a methodological point of view, the econometric tool we use enables us to perform a more thorough analysis by incorporating the presence of structural breaks and cointegration methods by means of maximum likelihood, which corrects bias in small samples. This is relevant, since previous studies looking at Mexico have used relatively simple techniques, such as regressions in first differences, or the Engle-Granger cointegration test.

The main results are as follows: i) there is evidence to affirm that there is a long-term relationship between GDP and total public investment, and also each of its components; (ii) total public investment has a positive and significant impact on economic activity, as do each of its components; iii) of all the components considered, those which have the greatest impact on GDP are investment in industrial development (primarily the state-owned oil company Petróleos Mexicanos [PEMEX] and Federal Electricity Commission [CFE]) and investment in transport and communications; (iv) the results suggest that total public investment has a complementary rather than a crowding-out effect on private investment, as do each of its components; (v) investment in social development (mainly schools and hospitals) and in transport and communications are estimated to have the greatest effect on private investment.

\footnotetext{
4 INEGI’s compilation of historical statistics, Estadísticas Históricas de México (or EHM), provides data going back as far as the late nineteenth and early twentieth centuries. However, there are gaps in this information due to the revolutionary period.

5 See Abiad et al. (2015), Cournede and Denk (2015), Easterly and Rebelo (1993), Fernald (1999), and Warner (2014), just to mention a few.

6 Of the authors mentioned above, Noriega and Fontenla (2007) are the only ones to consider the impact of different physical infrastructure components, namely industrial (kilowatts of electricity) and communications (roads and telephone lines).
} 
The remainder of this article is organized as follows. Section 2 presents the database. Section 3 includes the estimates and results. Finally, Section 4 contains the final remarks.

\section{Sources and Data}

The series used in this study are: GDP, total federal public investment (and its components), and private investment, all for the period 1925-1981. The GDP series was obtained from the historical GDP series (from 1900 to 1995) in 1980 prices. ${ }^{7}$ Graph 1 shows the evolution of the GDP series converted into 2003 prices. ${ }^{8}$

The total public investment series and its components were constructed using INEGI's compilation of historical statistics, Estadísticas Históricas de México (EHM). The total public investment series has five components. Most of the series are available from 1925 until 1996 and all of them were converted into 2003 prices.

The private investment series was constructed using information on gross fixed capital formation (GFCF) by type of buyer (private). The data was taken from Cárdenas (1996, Tables III.6, II.2, and I.3) and Cárdenas (1994, Table A.28), which show private GFCF in millions of current pesos, converted into 2003 prices with the aforementioned deflator series. Graph 2 shows the evolution of these two variables. The private investment series has a greater volatility

Graph 1: Gross Domestic Product, millions of pesos 2003 (in logarithms)

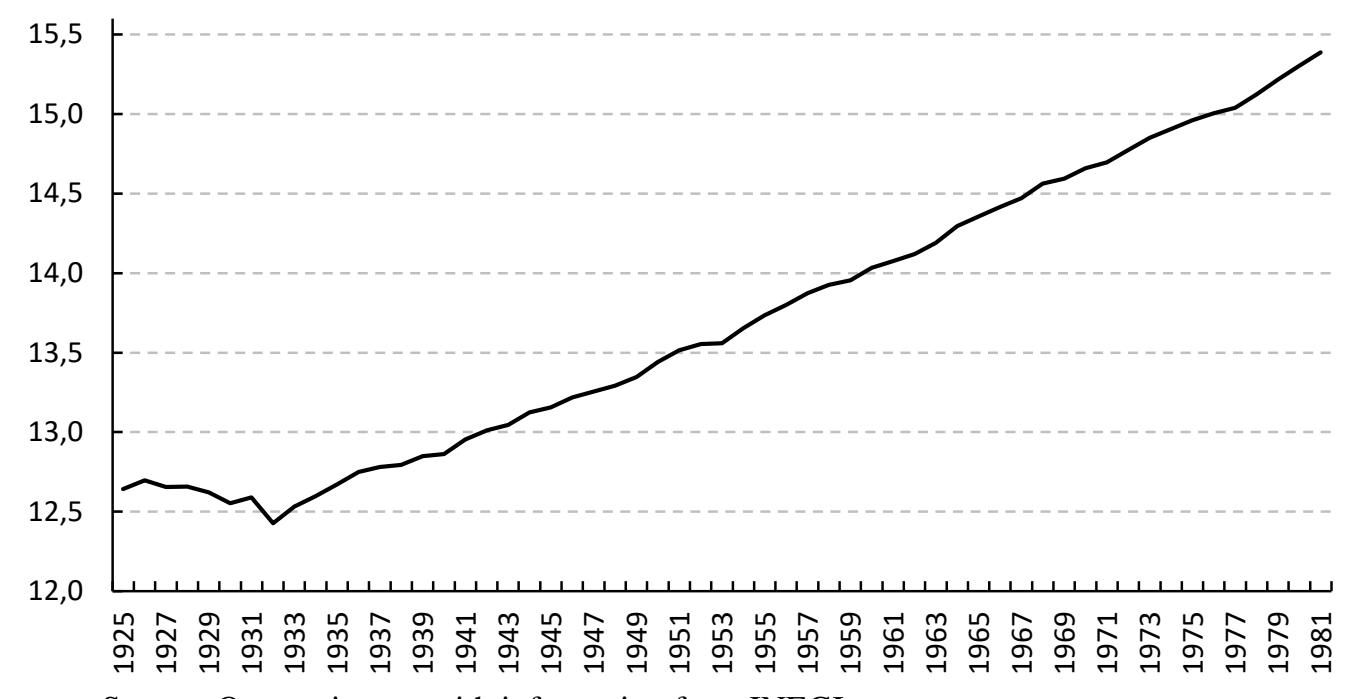

Source: Own estimates with information from INEGI.

\footnotetext{
7 This series is available in the Economic Information Bank (Banco de Información Económica, or BIE) section of INEGI's website.

8 The conversion of the original GDP series into 2003 prices was achieved by simple chaining with the current GDP series, in 2003 prices (also available at the INEGI website).
} 
than the public investment series, particularly in the period from the early 1930s until the end of the Second World War.

Graph 3 shows the investment series (both public and private) as a percentage of GDP. From the beginning of the sample up to 1945, total (public plus private) investment exceeded 5 percent of GDP in only eight years, though never rose above 7 percent. During the subsequent period of Mexico’s “economic populism” (Bazdresch and Levy, 1991), there was a sustained increase in total investment. In terms of share of GDP, total investment grew gradually: having been close to 10 percent in 1950, it increases to 23 percent by the end of the sample (and prior to the 1982 crisis).

Graph 2: Public and private investment, millions of pesos 2003 (in logarithms)

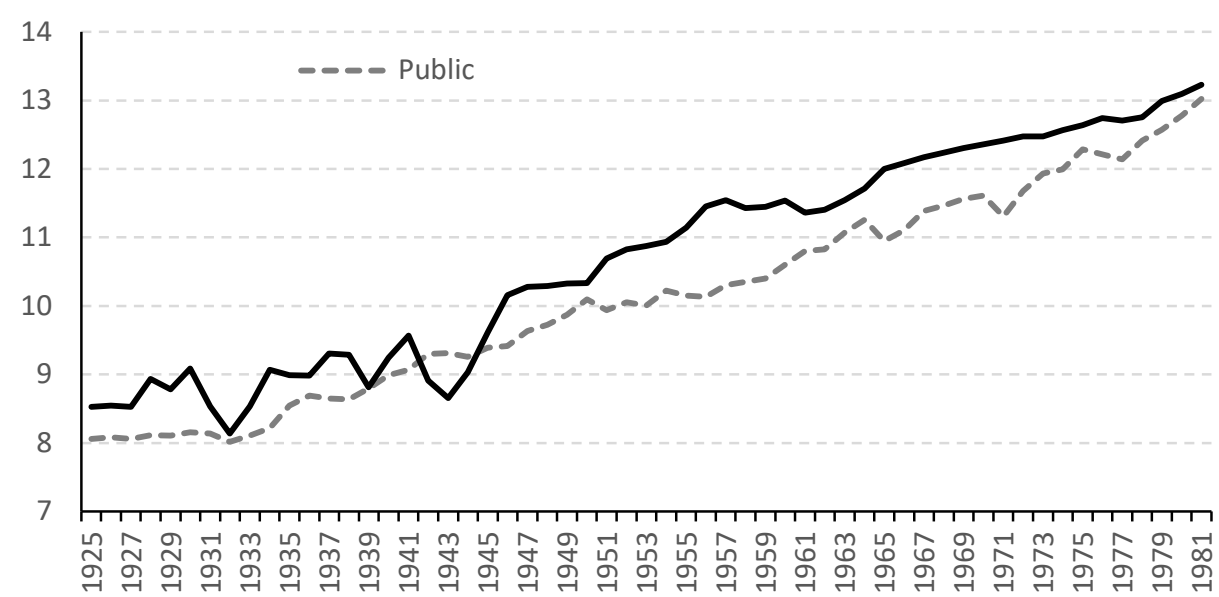

Source: Own estimates with information from INEGI.

Graph 3: Public and private investment as a percentage of GDP

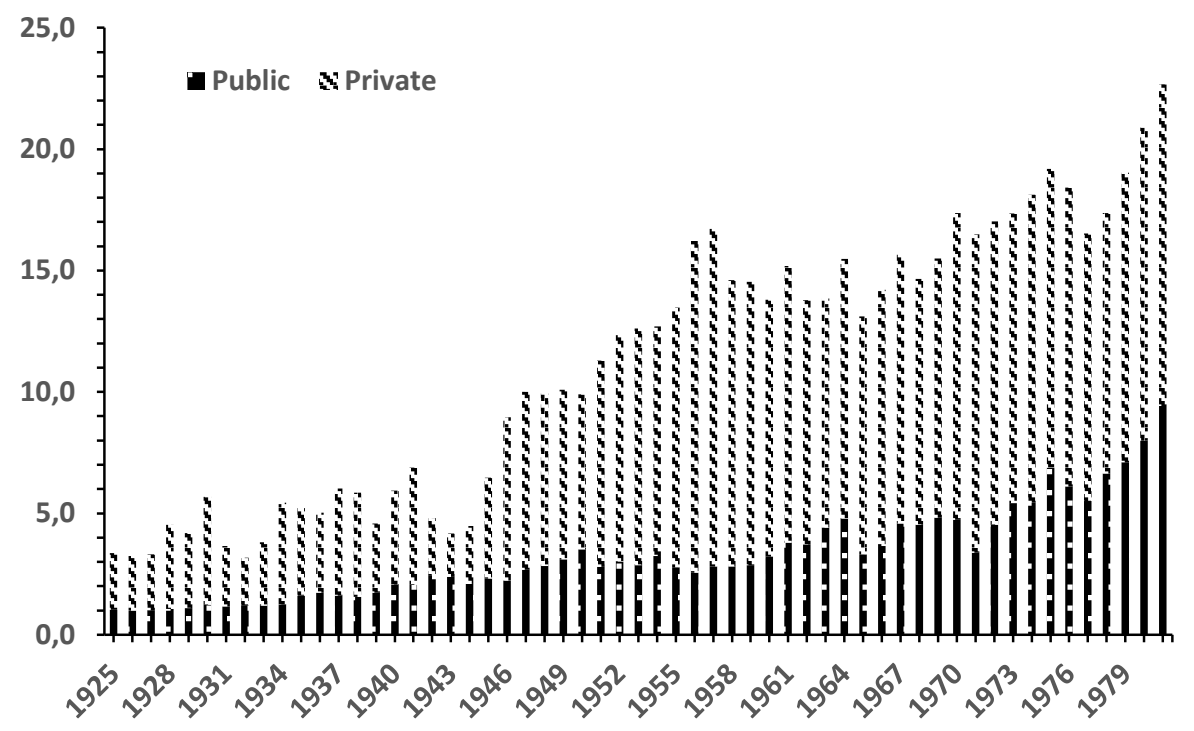

Source: Own estimates with information from INEGI and Cárdenas $(1994,1996)$. 
Total federal public investment can be broken down into the following components: agricultural development, which includes investment in agriculture, irrigation, and livestock (traces); industrial development. e.g., investment in State-Owned Enterprises (SOEs), which includes investment in the energy sector (electricity, oil, and gas), mining, and related industries; transport and communications, i.e., investment in roads, railways, airports, ports, and communication routes in general; social development, which primarily includes investment in education and health, and finally; government administration, which considers investment in justice, security, defense, and other government administration functions. Due to differences in the availability of information, the start years for the data on investment in industrial development and government administration are, respectively, 1938 and 1939, while that for all other concepts is 1925.

Graph 4 shows the share each component represents of total public investment during the period studied. The first thing to notice is the marked fall in the relative share of transport and communications, which initially constituted the most important component of total public investment (i.e., 75 percent in 1925), a position it maintained until the early 1950s. Its importance then began to decline, and continued to do so throughout the remaining years of the sample, eventually falling to just 15 percent.

While the relative share of transport and communications in total investment decreased, that of social development increased, reaching a peak in the 1960s of around 30 percent. However, the component that shows the most significant increase in terms of its relative importance was investment in industrial development, whose share increased from 1938 (the first year for which

Graph 4: Evolution of the components of public investment in relation to the total (in percentages)

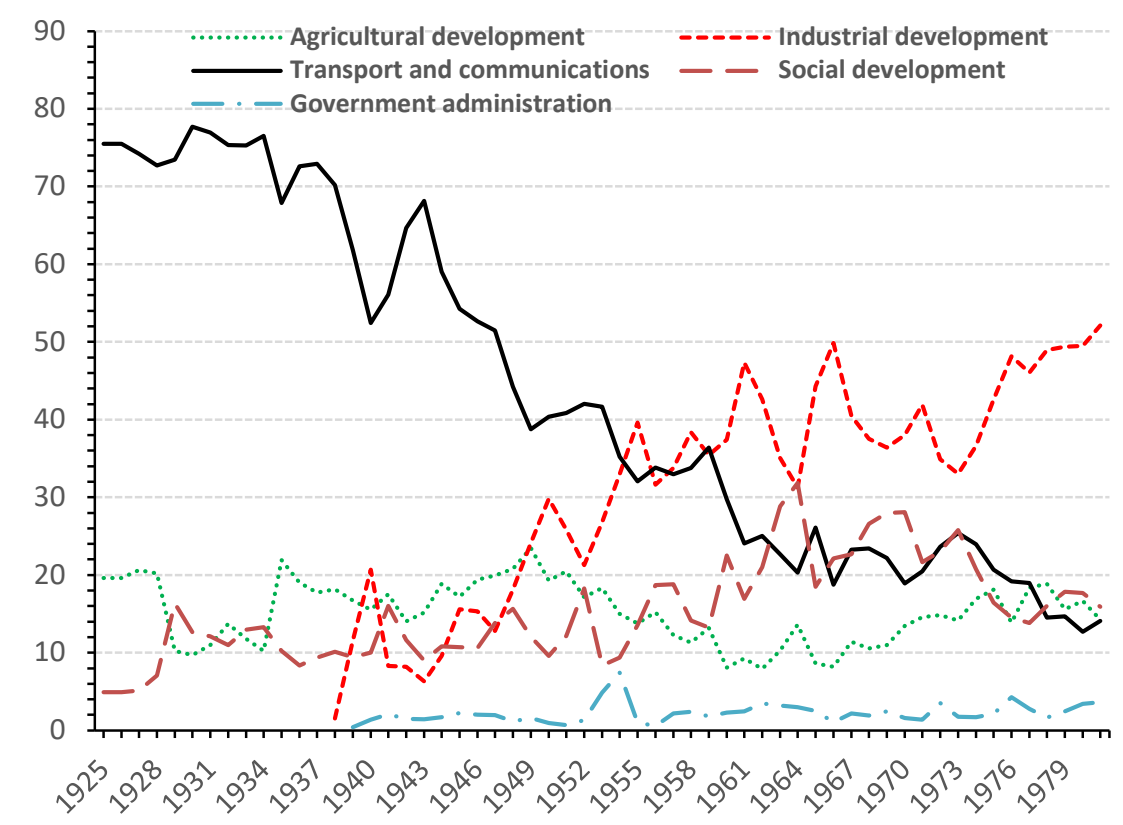

Source: Own estimates with information from INEGI. 
data is available) to 1960. During the period 1960-1973, its share fluctuated around 40 percent, then began to rise. This spurt of growth continued thanks to the boom in the oil industry and by the end of the period investment in SOEs accounted for just over half of all federal public investment.

The two other components, investment in agricultural development and investment in government administration were, on average, the lowest and most constant components in terms of their share of total public investment, i.e., 15 and 3 percent, respectively.

\section{$3 \quad$ Empirical Analysis and Results}

The purpose of this section is fourfold. First, we begin by analyzing the statistical properties of the series, defining their order of integration and testing for the presence of structural breaks in order to ensure they are suitable for a cointegration analysis. Second, we specify the model and propose some relevant parametric restrictions that allow us to (i) identify the model and (ii) obtain equations that can be easily interpreted. Thirdly, we interpret and discuss our estimations of the long-run relationship between GDP and public investment, and between private investment and public investment (both total and by individual component). Finally, we analyze the short-run dynamics of the Impulse-Response Functions (IRF) and the Forecast Error Variance Decomposition (FEVD).

\subsection{Statistical Properties of the Series}

Table 1 (Columns 1 to 4) shows the results of standard unit-root tests, i.e., the Augmented Dickey-Fuller (ADF), Dickey-Fuller-GLS (DF-GLS), Kwiatkowski-Phillips-Schmidt-Shin (KPSS), and Phillips-Perron (PP) tests, respectively. All of these show that there is not enough evidence to reject the null hypothesis of unit root, ${ }^{9}$ i.e., the series cannot be considered stationary processes. ${ }^{10,11}$ Columns 5 and 6 of Table 1 present the statistics associated with two procedures (the Exact Local Whittle [Shimotsu and Phillips, 2005] and GPH [Geweke and Porter-Hudak, 1983]) that estimate the degree of fractional integration. For all the series, both procedures yield estimates that are statistically different from zero, which is consistent with the results from the first standard unit-root tests. Finally, Column 7 shows the test statistics of Ventosa-Santaulària and Gómez-Zaldívar (2010). This last test allows us to distinguish between the null hypothesis of a driftless unit-root process and the alternative hypothesis of a unit-root process with drift. The results indicate that all of the series save for government administration

\footnotetext{
9 It is worth remembering that, in contrast to all the other tests, the null hypothesis of the KPSS test is stationarity. For the variables of this study, this hypothesis was rejected.

10 Investment in industrial development is the only series for which the outcome is different: the PP test indicates that it is indeed possible to reject the null of unit root; however, this occurs with a $10 \%$ significance level.

11 The results of these tests, applied to the series in first differences, indicate that they can be considered I(0) processes.
} 
and the price of oil have not only a stochastic trend (the unit-root process) but also a deterministic trend.

Using the Bai and Perron (1998, 2003) testing procedure, we also test for possible structural breaks in the (differenced) series. Had we found evidence of such structural breaks, we would have had to model these in the cointegration analysis. However, the results yielded evidence of a level break for GDP only.

Table 1: Unit-root and persistence tests

\begin{tabular}{lccccccc}
\hline \multicolumn{1}{c}{ Variable } & ADF & GLS & KPSS & $P P$ & Whittle & $G P H$ & $G V S$ \\
\hline Mexican GDP $\left(Y_{t}\right)$ & 1.690 & -0.340 & $1.505^{* * *}$ & 2.598 & $1.019^{* * *}$ & $1.046^{* * *}$ & $0.997^{* * *}$ \\
$\begin{array}{l}\text { Private investment }\left(I_{t}\right) \\
\text { Total public investment } \\
\left(G_{t}\right)\end{array}$ & -0.118 & 0.090 & $1.504^{* * *}$ & -0.103 & $0.880^{* * *}$ & $0.913^{*}$ & $0.965^{* * *}$ \\
$\begin{array}{l}\text { Social development } \\
\left(S D_{t}\right)\end{array}$ & -0.003 & 0.819 & $1.527^{* * *}$ & -0.526 & $0.773^{* * *}$ & $0.794^{* * *}$ & $0.975^{* * *}$ \\
$\begin{array}{l}\text { Industrial development } \\
\left(I D_{t}\right)\end{array}$ & -1.355 & 0.836 & $1.194^{* * *}$ & $2.614^{*}$ & $0.931^{* * *}$ & $0.963^{* * *}$ & $0.962^{* * *}$ \\
$\begin{array}{l}\text { Transport } \\
\text { communications }\left(T C_{t}\right)\end{array}$ & 0.767 & -0.204 & $1.483^{* * *}$ & 0.611 & $0.867^{* * *}$ & $0.949^{* * *}$ & $0.972^{* * *}$ \\
$\begin{array}{l}\text { Agricultural } \\
\text { development }\left(A D_{t}\right)\end{array}$ & 0.797 & 0.315 & $1.425^{* * *}$ & 0.587 & $1.017^{* * *}$ & $1.045^{* * *}$ & $0.951^{* *}$ \\
$\begin{array}{l}\text { Government } \\
\text { administration }\left(G A_{t}\right)\end{array}$ & 0.449 & 0.987 & $1.170^{* * *}$ & -1.614 & $0.625^{* * *}$ & $0.777^{* * *}$ & 0.867 \\
\hline $\begin{array}{l}\text { Brent price }\left(P_{t}\right) \\
\text { US GDP }\left(Y_{t}^{u s}\right)\end{array}$ & -1.293 & -0.532 & $0.451^{*}$ & -0.200 & $0.895^{* * *}$ & $0.961^{* *}$ & 0.877 \\
\hline
\end{tabular}

$\S$ The specification of the auxiliary regression includes a constant. The maximum number of lags was determined by $L_{\max }=\left[12(T / 100)^{1 / 4}\right]$. The symbols $* * *, * *$, and $*$ denote rejection of the null at the 1,5 , and 10 percent level, respectively. The oil price series and US GDP series will be used in the cointegration analysis.

\subsection{Model Specification and Restrictions}

Having found evidence that all the variables behave as I(1) processes, we then perform a Johansen test (see Johansen, 1988, and Johansen and Juselius, 1990) to identify whether there is a long-run relationship between GDP, private investment, and public investment (both total and by individual component). In doing so, we include two exogenous variables in the cointegrated relationship: US GDP and the price of crude oil. ${ }^{12}$

\footnotetext{
12 These two variables are very important for the Mexican economy, particularly for the period being analyzed. On the one hand, Mexico and the US share a very highly integrated economic relationship, therefore, exogenous changes in US GDP had important consequences for Mexican GDP. On the other, government revenue during this period was
} 
The results of the Johansen trace test in Table 2 confirm that these three variables cointegrate. We show that in all six cases it is possible to reject the null hypotheses of zero and one cointegrating vectors, but not the null of two cointegration vectors. These estimations imply that there are two cointegrated vectors for each type of public investment analyzed. The order of the VEC, i.e., the number of lags selected for each of the series, is shown in the last column.

The cointegrated equations with the three variables of interest and the two exogenous variables are shown in Equations (1) and (2): 13

$$
\begin{aligned}
& \beta_{1,0}+\beta_{1,1} Y_{t}+\beta_{1,2} I_{t}+\beta_{1,3} G_{t}+\gamma_{1,1} Y_{t}^{U S}+\gamma_{1,2} P_{t} \sim I(0) \\
& \beta_{2,0}+\beta_{2,1} Y_{t}+\beta_{2,2} I_{t}+\beta_{2,3} G_{t}+\gamma_{2,1} Y_{t}^{U S}+\gamma_{2,2} P_{t} \sim I(0)
\end{aligned}
$$

The short-run (VEC) equations are shown in Equations (3), (4), and (5):

$$
\begin{aligned}
& \Delta Y_{t}=\sum_{i=1}^{k} \delta_{1 i} \Delta Y_{t-i}+\sum_{i=1}^{k} \delta_{2 i} \Delta I_{t-i}+\sum_{i=1}^{k} \delta_{3 i} \Delta G_{t-i}+\emptyset_{1} W W I I_{t}+\emptyset_{2} P C_{t}+\alpha_{1,1} \mathrm{ECM}_{1 t-1}+\alpha_{1,2} \mathrm{ECM}_{2 t-1} \\
& \Delta I_{t}=\sum_{i=1}^{k} \delta_{4 i} \Delta Y_{t-i}+\sum_{i=1}^{k} \delta_{5 i} \Delta I_{t-i}+\sum_{i=1}^{k} \delta_{6 i} \Delta G_{t-i}+\emptyset_{3} W W I I_{t}+\emptyset_{4} P C_{t}+\alpha_{2,1} \mathrm{ECM}_{1 t-1}+\alpha_{2,2} \mathrm{ECM}_{2 t-1} \\
& \Delta G_{t}=\sum_{i=1}^{k} \delta_{7 i} \Delta Y_{t-i}+\sum_{i=1}^{k} \delta_{8 i} \Delta I_{t-i}+\sum_{i=1}^{k} \delta_{9 i} \Delta G_{t-i}+\emptyset_{5} W W I I_{t}+\emptyset_{6} P C_{t}+\alpha_{3,1} \mathrm{ECM}_{1 t-1}+\alpha_{3,2} \mathrm{ECM}_{2 t-1}
\end{aligned}
$$

There is one equation for each of the three endogenous variables; the first three terms of each equation are lagged differences of the endogenous variables included to control for temporal dynamics, as is usual in a VAR approach; $W W I I_{t}$ and $P C_{t}$ are dummy variables, the former is to control for the relationship among the variables during the years of World War II (WWII) and the latter, Political Cycle (PC), is to control for the different presidential periods during the sample analyzed; ${ }^{14}$ finally, the last two terms are the error-correction mechanisms (ECMs), whose statistical significance allows us to infer which variables adjust whenever there is a disequilibrium in the long-run relationship (i.e., which variables are not weakly exogenous).

In order to (i) allow a valid interpretation of the parameters of the VEC and (ii) provide a more intuitive representation of the cointegrating relationships, we test the following restrictions shown in Table 3, Panel (a) in the long-run equations, along with the short-run restrictions (on the ECMs) shown in Table 3, Panel (b).

The set of four restrictions on the cointegrating parameter ensures identification of the VEC. 15 Two of these restrictions are trivially obtained by normalizing one parameter of each

highly dependent on oil exports, therefore, exogenous changes in the international oil price had a significant effect on government revenues and, as a consequence, on public investment.

13 There are a couple of equations similar to (1) and (2) for each of the components of total public investment.

14 For an analysis of the PC using long series (1957-1997) in Mexico see González (2002).

15 The goal is to obtain an estimate of $\Pi=\alpha \beta^{\prime}$ with cointegration rank $r$, where $\beta$ contains the cointegration vectors and $\alpha$ includes the loading parameters (adjustment velocities), i.e., the parameters that measure the process of adjustment of the endogenous variables to a disequilibrium in the previous period. Identification of the VEC is guaranteed if the number of restrictions equals $r^{2}$. In this case, given that there are two cointegration vectors, the number of restrictions should be equal to 4. Following Johansen (2005), excluded variables in one cointegrating 
Table 2: Results of the cointegration tests

\begin{tabular}{lcccc}
\hline \multirow{2}{*}{$\begin{array}{c}\text { Public investment series included in } \\
\text { the cointegration test }\end{array}$} & $\begin{array}{c}\mathrm{H}_{0}: 0 \\
\text { cointegrating } \\
\text { vectors }\end{array}$ & $\begin{array}{c}\mathrm{H}_{0}: 1 \\
\text { cointegrating } \\
\text { vectors }\end{array}$ & $\begin{array}{c}\mathrm{H}_{0}: 2 \\
\text { cointegrating } \\
\text { vectors }\end{array}$ & $\begin{array}{c}\text { Selected } \\
\text { lags* }\end{array}$ \\
\hline Total public investment $\left(G_{t}\right)$ & $87.24^{* * *}$ & $31.73^{*}$ & 8.86 & 6 \\
Industrial development $\left(I D_{t}\right)$ & $105.81^{* * *}$ & $48.96^{* * *}$ & 15.40 & 7 \\
Transport and communications $\left(T C_{t}\right)$ & $61.39^{* * *}$ & $26.16^{* * *}$ & 7.61 & 5 \\
Social development $\left(S D_{t}\right)$ & $73.47^{* * *}$ & $40.13^{* * *}$ & 12.38 & 6 \\
Government administration $\left(G A_{t}\right)$ & $103.06^{* * *}$ & $49.14^{* * *}$ & 9.42 & 6 \\
Agricultural development $\left(A D_{t}\right)$ & $64.21^{* * *}$ & $26.36^{* *}$ & 10.5 & 6 \\
\hline
\end{tabular}

- The trace test employs small-sample critical values suited to the number of observations in our samples." The number of lags was determined using the Akaike Information Criteria for VARs. The number in the last column of the table refers to $\mathrm{k}=\mathrm{p}-1$. The symbols $* * *$ and $* *$ denote rejection of the null at the 1 and 5 percent level, respectively.

Table 3: Restrictions

Panel (a). Long-run restrictions (identical for all long-run equations)

$\begin{array}{cc}\text { Long-run Equation } 1 & \text { Long-run Equation } 2 \\ \boldsymbol{\beta}_{\mathbf{1 , 1}}=\mathbf{1} & \beta_{2,1}=0 \\ \boldsymbol{\beta}_{\mathbf{1 , 2}}=\mathbf{0} & \beta_{2,2}=1\end{array}$

Panel (b). Short-run restrictions

Relationship of $Y_{t}$ to: $\quad$ Relationship of $I_{t}$ to:

Total public investment $\left(G_{t}\right)$

Industrial development $\left(I D_{t}\right)$

Transport and communications $\left(T C_{t}\right)$

Social development $\left(S D_{t}\right)$

Government administration $\left(G A_{t}\right)$

Agricultural development $\left(A D_{t}\right)$

$$
\begin{gathered}
\alpha_{1,3}=0 \\
\alpha_{1,2}=0 \quad \alpha_{1,3}=0 \\
\alpha_{1,3}=0 \\
\alpha_{1,2}=0 \quad \alpha_{1,3}=0 \\
\alpha_{1,3}=0 \\
\alpha_{1,2}=0
\end{gathered}
$$$$
\alpha_{2,1}=0
$$$$
\alpha_{3,2}=0
$$$$
\alpha_{3,2}=0
$$$$
\alpha_{3,2}=0
$$$$
\alpha_{3,2}=0
$$$$
\alpha_{3,2}=0
$$

cointegrated vector (CV). We set the other two as a slight modification of the standard Phillips normalization by setting one parameter in each CV equal to zero in such a way that the first CV relates GDP to Public Investment (the main core of the paper), with a second that relates Private

vector (private investment in Equation 1, GDP in Equation 2) can be conceived as instruments. In short, when the parameters are identified by the zero restrictions, the usual "partial derivative" interpretation of such parameters remains valid. In our case, given that the variables are transformed into logs, they can be interpreted as long-run elasticities. Further details can be found in Johansen (2005). 
Investment to Public Investment, a natural vehicle to test crowding out. As attractive as these restrictions may prove in terms of interpretability, it is not possible to test their validity due to the fact that the system is precisely identified. We therefore take advantage of the possibility of testing the ECMs for significance. The ECM restrictions we test are data-driven, i.e., they are set based on what can be inferred from the individual t-ratios associated with the ECMs in the short-run equations (see Table 3, Panel (b)). The over-identifying restrictions allow us to test the validity of the entire set of restrictions (long-run parameters and ECMs). In all cases, we cannot reject the null hypothesis of restriction validity. The results are shown in Table $4 .{ }^{16}$ In other words, if the restrictions are valid, the relationship between GDP and public investment and between private investment and public investment can be presented in a more intuitive form. To be precise, Equations (1) and (2) can be expressed as shown in Equations (6) and (7), respectively: ${ }^{17}$

$$
\begin{gathered}
Y_{t}=-\beta_{1,0}-\beta_{1,3} G_{t}-\gamma_{1,1} Y_{t}^{U S}-\gamma_{1,2} P_{t} \\
I_{t}=-\beta_{2,0}-\beta_{2,3} G_{t}-\gamma_{2,1} Y_{t}^{U S}-\gamma_{2,2} P_{t}
\end{gathered}
$$

In Equation (6), parameters $\beta_{13}$ measure the impact on GDP of each type of public investment; the values estimated allow us to identify which type of public investment had the greatest impact on GDP or the elasticity of GDP with respect to each type of public investment. In Equations (7), parameters $\beta_{23}$ allow us to distinguish the type of relationship between each type of public investment and private investment during the period of study, and enable us to establish whether the two types of investment are complementary or if there is a crowding-out effect between them.

Table 4: Restrictions test

\begin{tabular}{lccc}
\hline \multicolumn{1}{c}{ Series } & $L_{U R}$ & $L_{R}$ & $2 *\left(L_{U R}-L_{R}\right)$ \\
\hline Total public investment $\left(G_{t}\right)$ & 208.078 & 206.438 & 3.281 \\
Industrial development $\left(I D_{t}\right)$ & 213.501 & 212.246 & 2.509 \\
Transport and communications $\left(T C_{t}\right)$ & 180.887 & 180.783 & 0.207 \\
Social development $\left(S D_{t}\right)$ & 158.671 & 156.891 & 3.560 \\
Government administration $\left(G A_{t}\right)$ & 153.229 & 151.416 & 3.62 \\
Agricultural development $\left(A D_{t}\right)$ & 168.205 & 168.088 & 0.233 \\
\hline
\end{tabular}

16 Table 4 shows the results of testing all of the aforementioned restrictions for each type of public investment. The first and second columns show the log-likelihoods of the unrestricted and restricted model, respectively. The test statistic is shown in the third column; the null hypothesis is that the restrictions are valid and the alternative hypothesis is that at least one is not.

17 Note that the signs of the parameters of the cointegrated variables are negative. This is due to the fact that the proper presentation of a cointegrated equation is a linear combination of I(1) variables that yields an I(0) variable; however, Equations (3) and (4) show such cointegrated equations in a more classic "regression" framework, in which there is a "dependent variable" and "controls" for ease of comprehension. Of course, this representation entails no causal link whatsoever. 


\subsection{The Long-run Relationship}

Table (5) shows the estimated parameters of Equations (6) and (7).

Table 5: Estimated parameters of normalized equations

\begin{tabular}{|c|c|c|c|c|c|c|c|c|}
\hline \multirow[b]{2}{*}{ Series } & \multicolumn{4}{|c|}{ Equation (6) } & \multicolumn{4}{|c|}{ Equation (7) } \\
\hline & $\beta_{1,0}$ & $\beta_{1,3}$ & $\gamma_{1,1}$ & $\gamma_{2,1}$ & $\beta_{2,0}$ & $\beta_{2,3}$ & $\gamma_{1,2}$ & $\gamma_{2,2}$ \\
\hline Total public investment $\left(G_{t}\right)$ & -2.33 & 0.16 & ---- & ---- & 26.82 & 2.86 & ---- & ---- \\
\hline Industrial development $\left(I D_{t}\right)$ & 24.9 & 1.90 & -2.94 & ---- & 3.28 & 0.55 & ---- & 0.11 \\
\hline $\begin{array}{ll}\text { Transport } & \text { and } \\
\text { communications }\left(T C_{t}\right) & \end{array}$ & 4.85 & 1.02 & ---- & ---- & -1.35 & 1.39 & ---- & ---- \\
\hline Social development $\left(S D_{t}\right)$ & 8.17 & 0.51 & --- & 0.13 & 4.53 & 0.60 & ---- & ---- \\
\hline $\begin{array}{l}\text { Government administration } \\
\left(G A_{t}\right)\end{array}$ & 7.11 & 0.41 & 0.59 & --- & -4.91 & 0.08 & 1.80 & ---- \\
\hline $\begin{array}{l}\text { Agricultural development } \\
\left(A D_{t}\right)\end{array}$ & 9.91 & 0.42 & ---- & ---- & 8.84 & 0.73 & ---- & ---- \\
\hline
\end{tabular}

* Parameters associated with restricted exogenous variables are removed from the specification if they are not statistically significant at the $5 \%$ level.

Our estimates from Equation (6) suggest that the component with the greatest impact on $Y_{t}$ (i.e., that which produces the highest long-run elasticity ${ }^{18}$ ) is investment in industrial development (SOEs), with an estimated elasticity of 1.90. This result is consistent with the fact that the country's output during the period was highly dependent on SOEs. This particular type of investment boosted demand for energy, (i.e., oil and electricity), not only through its direct impact on GDP but also indirectly, through the resulting positive externalities for other Mexican industries, which were provided with the energy they needed to produce, possibly at lower prices. Cárdenas (2015), for example, notes that during the oil boom, public investment in this sector enabled the growth of related sectors through Hirschman-type linkages, due to the fact that oil requires inputs for its expansion; this, in turn, allowed the expansion of other sectors through the availability of foreign currency and generated fiscal resources to be used in other sectors (Cárdenas, op. cit., p. 632).

The second highest GDP sensitivity is that with respect to investment in transport and communications, for which the elasticity is estimated at 1.02. ${ }^{19}$ In nineteenth-century Mexico, the general lack of any effective system of transport and communications represented a major obstacle to the growth of both production and trade. During the Porfiriato period (1876-1910),

\footnotetext{
18 Henceforth, we shall refer to long-run elasticity as simply elasticity for short.

19 This is in line with other international studies in which investment in transport and communications has been identified as one of the most important determinants of GDP growth; see, for example, Easterly and Rebelo (1993) and Canning and Fay (1993).
} 
the government invested heavily in the country's rail network. Between 1880 and 1910, this network grew from 1,074 km to 19,280 km, providing rail links between the country's capital and its other major cities, as well as connections to the country's export regions. ${ }^{20}$ Given that our period of study begins almost immediately after the end of the Mexican Revolution (an event during which many important channels of communication were destroyed), the high elasticity of GDP with respect to investment in transport and communications is logical, since the latter stimulated production and trade, which had stagnated during the revolutionary period. Guajardo et al. (2010) point out that rail infrastructure and services suffered a severe physical deterioration due to the Revolution. They further state that from the 1930s on, roads and motor transport began to assume-in a slow and rudimentary way-the function previously performed by the railroads (Guajardo et al., op. cit., p. 701).

The third highest GDP sensitivity is that with respect to investment in social development, for which the elasticity is estimated at 0.51; although, like the previous two, it is positive and significant, it is inelastic. This type of investment included, for example, the creation of the Mexican Social Security Institute (IMSS) in 1943, the government organization responsible for public health, pensions, and social security, which contributed to enhancing the individual and collective health and well-being of workers, thus impacting the economic growth of the country.

The elasticity of GDP with respect to investment in government administration and with respect to agricultural development are lower, implying that these types of investment did not bring about any significant increase in economic activity. Meanwhile, the elasticity we estimate with respect to total public investment is 0.160 , which is slightly higher than that estimated by Nazmi and Ramirez (1997), which is only 0.129.21

Why do we obtain a different result compared to their study, which analyzes a different period? Ilzetzki et al. (2013) may shed some light on this matter. They document how the macroeconomic effects of fiscal stimuli depend on key country-specific characteristics, such as their level of development, exchange rate regime, openness to trade, and public indebtedness. Our results are in line with two of their conclusions: i) the fiscal multiplier is relatively large in economies operating under predetermined exchange rates but is zero in economies operating under flexible exchange rates; 22 and ii) the fiscal multiplier in open economies is smaller than in closed economies. Mexico during the period analyzed was relatively closed compared to how it was after 1982.

\footnotetext{
20 The impact of railroads on growth in nineteenth-century Mexico and the Porfiriato period in particular has been studied by Coastworth (1979).

21 Nazmi and Ramirez (1997) are the only authors with whose result we can compare ours; to the best of our knowledge, they are the only ones who have performed this calculation.

22 During most of the period analyzed, Mexico's exchange rate was fixed, i.e., from April 1954 to August 1976; in September 1976, a controlled floating rate was introduced, which continued until August 1982. Since then, the exchange rate has been floating most of the time. From August 1982 to December 1982 there was what was called "generalized exchange rate control, ” and from December 1982 to August 1985 "exchange rate control”; from August 1985 to November 1991, there was a controlled floating exchange rate, then from November 1991 to December 1994 a controlled sliding rate with exchange rate bands; since December 1994 the exchange rate has been free floating. See Exchange regimes in Mexico, https://www.banxico.org.mx/mercados/d/\%7BC260B142-835E-2F6B-D7BD3C9E182BB8B9\%7D.pdf
} 
Our estimates from Equation (7) in Table 5 indicate that private and total public investment, as well as each of its components, are positively related. This finding contrasts with those of Nazmi and Ramirez (1997) and Lachler and Aschauer (1998), who estimate that the positive impact of public investment on growth was at the expense of private investment. Our results imply that public investment not only increases the aggregate demand for goods and services but also generates positive benefits for the various factors of production. During this period, Mexico had a relative paucity of capital goods, therefore public investment had a greater impact on the marginal productivity of private investment. Investment in transport and communications in particular lowered the cost of transporting raw materials and supplies and, therefore, the cost of commercial production, thus enhancing the productivity of private investment. Investing in industrial development not only has a direct effect by increasing aggregate demand but also an indirect effect, by providing the country with essential input factors (e.g., petroleum, gasoline, and electricity) at lower prices for all economic activities.

Evidence of the positive association between public investment and GDP in Mexico can be found in many other studies. Ramirez (1996) confirms the positive impact of public investment on economic activity; he estimates that a 10-percent increase in the growth rate of public investment would result in a 0.8-percent increase in the rate of productivity growth of real GDP. Lachler and Aschauer (1998) confirm that Mexico's total factor productivity growth responds positively to increases in the ratio of public to private investment. Feltenstein and Ha (1995) study the relationship between the provision of public infrastructure and the private output of different sectors in Mexico 23 in the period 1970-1990. Their results show that public expenditure on electricity and communications enhanced the productivity of private production in all sectors.

At the international level, Aschauer (1998) also confirms the importance of public capital to the growth rate of GDP. His empirical analysis is based on a cross section of 46 developing countries over the period 1970-1990. In general, all the studies we know of document a positive association between public investment and GDP.

\subsection{Short-run Dynamics}

\section{Impulse-Response Functions (IRF)}

It is important to quantify the short-run dynamics among endogenous variables. IRFs are the prototypical tool with which to do this in a VEC model and measure the reaction of each endogenous variable to exogenous shocks to the system. ${ }^{24}$

Let us begin with the total public investment model, ${ }^{25}$ according to which GDP reacts positively to a private investment shock, though the effect is only statistically significant for one

\footnotetext{
23 These sectors include mining, food products and tobacco, textiles, wood products, paper and printing, chemicals and petroleum, nonmetallic minerals, basic metals, machinery and equipment, other manufacturing products, construction, commerce and hotels, financial services, and medicine.

24 Shocks are generally defined as an increase of one standard deviation in the exogenous variable.

25 For brevity, we present only selected IRFs of the models using total public investment $\left(G_{t}\right)$, industrial development $\left(I D_{t}\right)$, and transport and communications $\left(T C_{t}\right)$. We chose the latter two components of total public
} 
period (one year); see Figure 1, Panel (a). Similarly, private investment reacts positively to an increase in GDP, though the effect is only significant for two periods after the shock; see Panel (b). The effect on private investment of a shock in total public investment is estimated as positive and statistically significant from year four to eight; see Panel (c).

In Figure 2, Panel (a), we can see that GDP reacts positively to a positive shock in SOE industrial development investment, its increase being statistically significant after period three. Panel (b) shows a similar response by private investment to an increase in SOE industrial development investment, one which, in this case, becomes statistically significant after five years. Panel (c) shows that SOE investment reacts favorably to a positive shock in SOE investment.

Figure 3, Panel (a) shows that GDP reacts positively to a positive shock in transport and communications investment, the increase being statistically significant only after year five. Panel (b) shows that investment in transport and communications increases when GDP increases, though its statistical significance is marginal. Panel (c) shows that investment in transport and communications reacts favorably to a positive shock in transport and communications investment.

\section{Forecast Error Variance Decomposition (FEVD)}

Now we provide the results of the FEVD of selected VAR models. FEVD helps us to understand how much of the forecast error variance of each of the variables in the system can be explained by each. Let us begin with the model that uses total public investment.

The information in Figure 4 implies that a considerable portion of private investment is explained by its own innovative shocks during the first two years, after which its own importance decreases. The dynamics of GDP contribute significantly to explaining private investment: GDP accounts for up to 50\% of private investment in the second and third years. The role of total public investment in explaining private investment is very limited during the initial years, though by the eighth year it accounts for up to $50 \%$ of it. This last result reflects the complementarity of both private and public investment, as identified previously. Very similar graphs for the private investment variance decompositions are found in the models with each type of component of public investment.

Figure 5 shows that (the forecast error variance of) GDP is explained primarily by its own innovative shocks during the first years, after which their importance diminishes. Private and public (in this case industrial) investment shocks have an increasing impact on (the forecast error variance of) GDP. This type of result is similar in all the other models and reflects the relative insignificance of private and public investment to short-run GDP, though their growing significance over time.

investment because according to our previous results they were the most relevant. All the other IRFs are available upon request. 
Figure 1: IRFs of the total public investment model

(a) Response of GDP to a shock in private investment

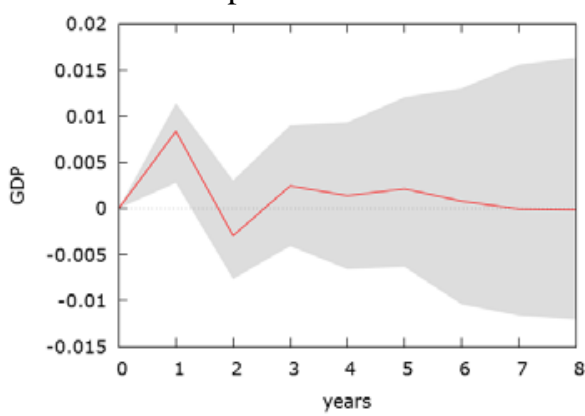

(b) Response of private investment to a shock in GDP

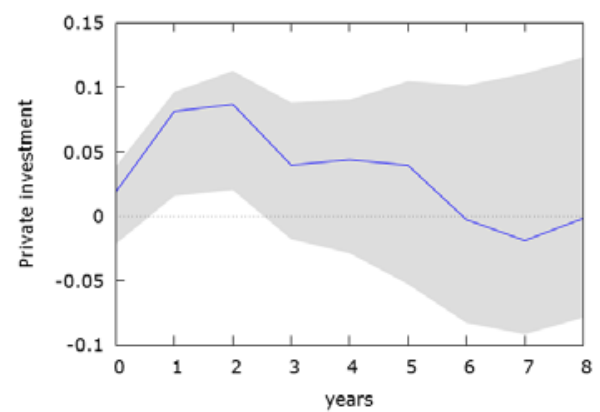

(c) Response of private investment to a shock in total public investment

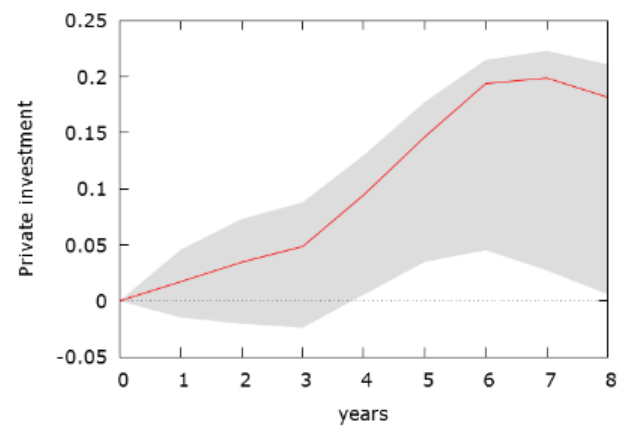

Figure 2: IRFs of the industrial development investment model

(a) Response of GDP to a shock in industrial development investment

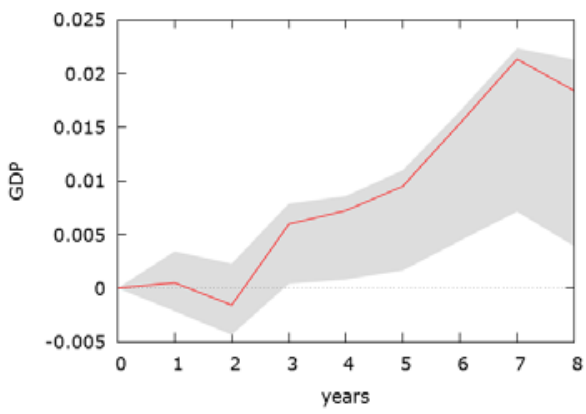

(b) Response of private investment to a shock in industrial development investment

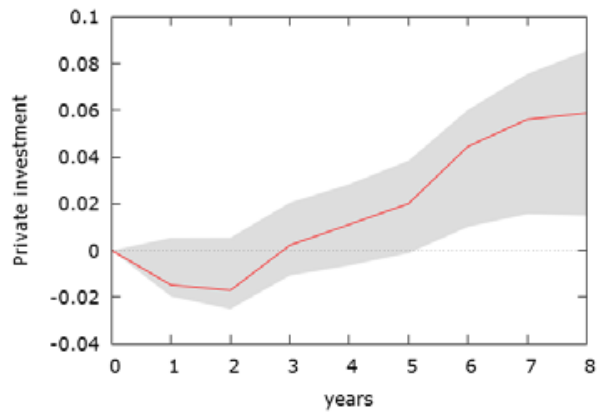

(c) Response of industrial development investment to a shock in industrial development investment

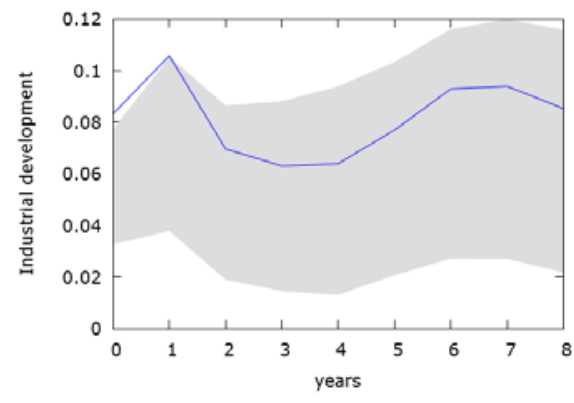


Figure 3: IRFs of the transport and communication investment model

(a) Response of GDP to a shock in Transport (b) Response of Transport and communiand communications investment cations to a shock in GDP
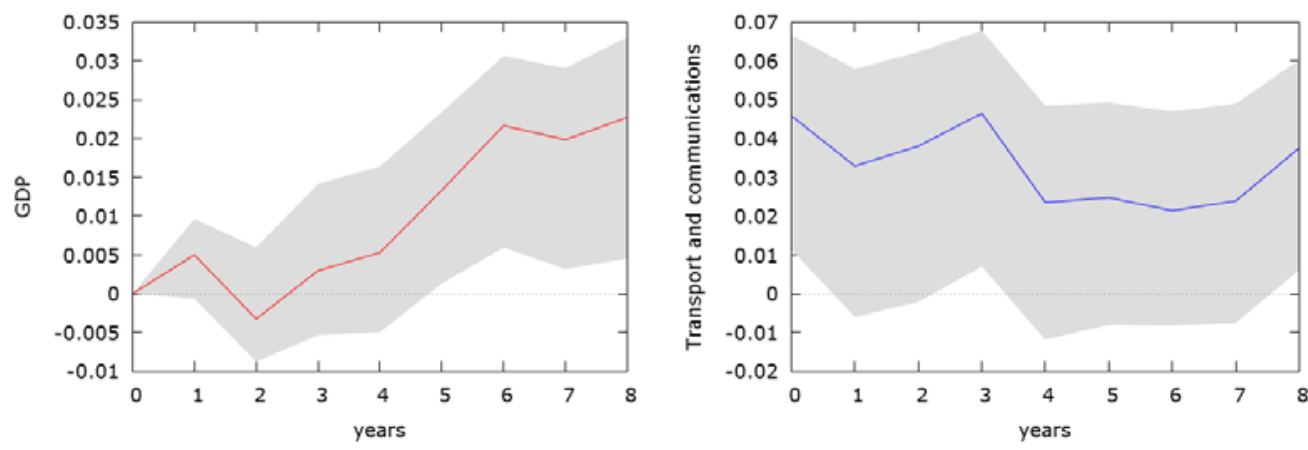

(c) Response of Transport and communications investment to a shock in Transport and communications investment

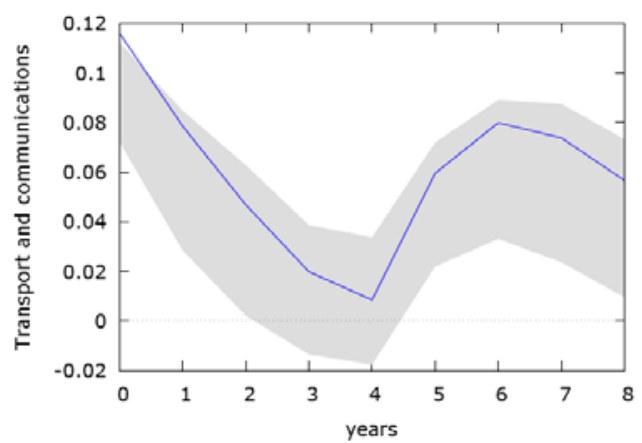

Figure 4: Variance decomposition of private investment, total public investment model

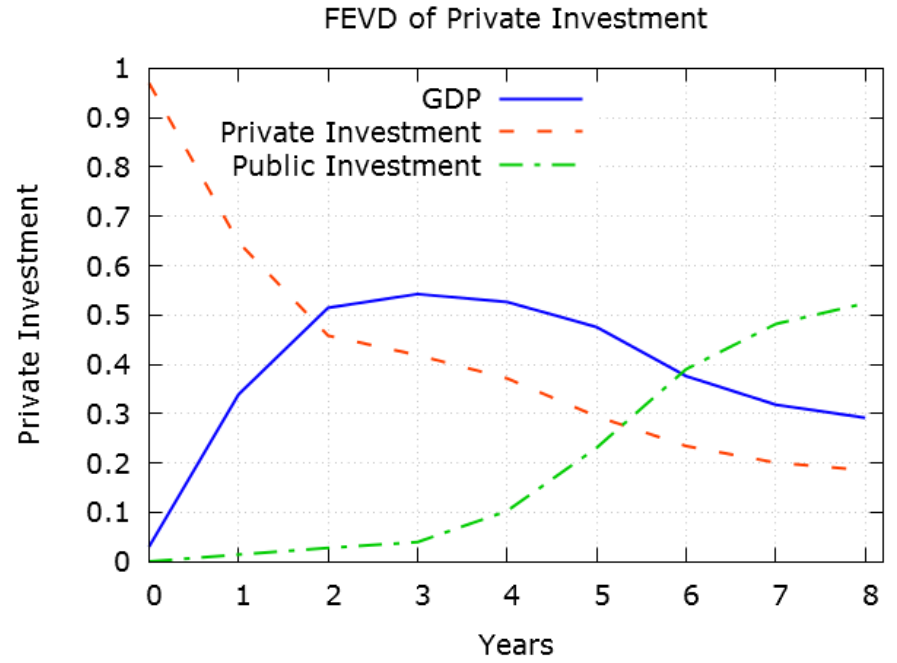


Figure 5: Variance decomposition of GDP, industrial investment (SOE) model

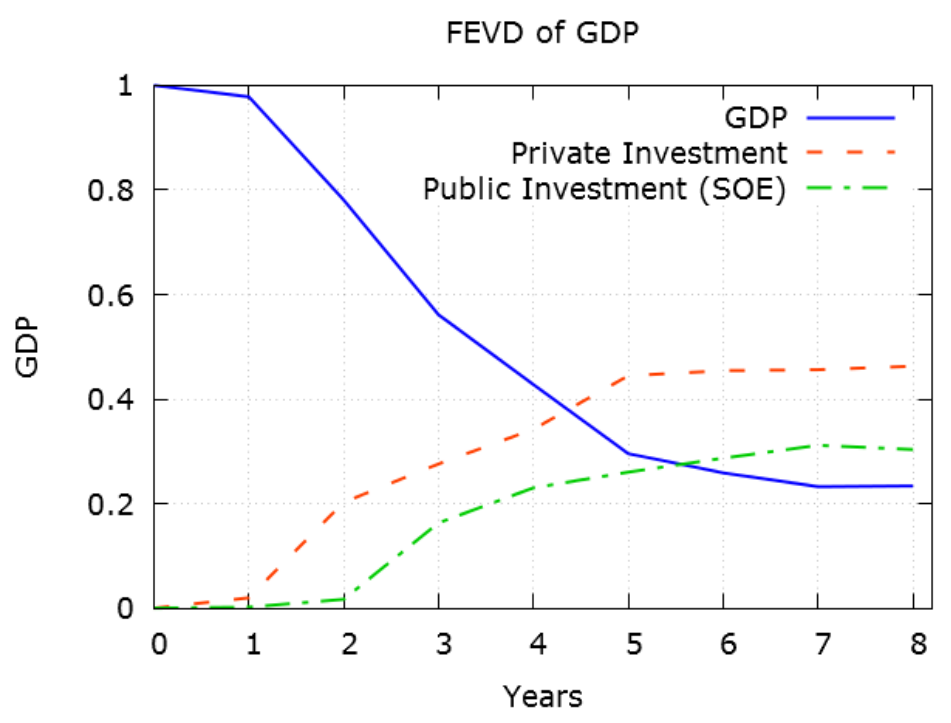

\section{$4 \quad$ Concluding Remarks}

Public investment is generally acknowledged as one of the main growth engines of the Mexican economy in the period from the end of the revolutionary war (1910-1920) until the late 1970searly 1980s. Nevertheless, previous literature provides no adequate evidence to support this assertion. By constructing a historical dataset just large enough to allow reasonable empirical analysis, we provide support for the argument that public investment was an important source of growth during this period.

Furthermore, our results indicate that both public and private investment have a positive impact on economic activity during the period studied, and that production is more sensitive to specific components of total public investment, i.e., investment in industrial development and investment in transport and communications. We also find that public investment has a complementary effect on private investment during this period, in some cases with elasticities above unity.

One promising line of research would be to investigate further whether public investment has crowded out or crowded in private investment in the contemporary period, one for which more disaggregated data exist. Previous studies that have attempted to answer this question failed to take into account a very important issue highlighted in economic theory: how does government finance investment? When government finances it by borrowing, it reduces the loanable funds available for private investment, driving up interest rates and reducing the level of private investment, thus the crowding-out effect. We believe that there is currently enough information to test the complementary hypothesis of public and private investment by incorporating all those theoretically relevant aspects that have not been taken into account in previous studies that analyze this issue during this period. 


\section{References}

Abiad, A., D. Furceri, and P. Topalova (2015). The Macroeconomic Effects of Public Investment: Evidence from Advanced Economies. IMF Working Paper No. 15/95. International Monetary Fund. https://ideas.repec.org/p/imf/imfwpa/15-95.html

Aschauer, D.A. (1998). The Role of Public Infrastructure Capital in Mexican Economic Growth. Economía Mexicana, Nueva Época, VII (1): 47-78.

http://www.economiamexicana.cide.edu/num_anteriores/VII-1/02_ASCHAUER_47-78.pdf

Bai, J., and P. Perron (1998). Estimating and Testing Linear Models with Multiple Structural Breaks. Econometrica 66(1): 47-78. https://www.jstor.org/stable/2998540

Bai, J., and P. Perron (2003). Computation and Analysis of Multiple Structural Change Models. Journal of Applied Econometrics 18(1): 1-22. https://doi.org/10.1002/jae.659

Barro, R. (1990). Government Spending in a Simple Model of Endogenous Growth. Journal of Political Economy 98(5): 103-125. https://dash.harvard.edu/handle/1/3451296

Branson, W. (1986). Macreoconomía. Teoría y Políticas. Fondo de Cultura Económica.

Canning, D., and M. Fay (1993). The Effect of Transportation Networks on Economic Growth. Manuscript, Columbia University.

https://academiccommons.columbia.edu/doi/10.7916/D80K2H4N

Cárdenas, E. (1994). La Hacienda Pública y la Política Económica en México, 1929-1958. Fondo de Cultura Económica.

Cárdenas, E. (1996). La Política Económica en México, 1950-1994. Fondo de Cultura Económica.

Cárdenas, E. (2015). El Largo Curso de la Economía Mexicana: de 1780 a nuestros días. Fondo de Cultura Económica/El Colegio de México.

Coatsworth, J.H. (1979). Indispensable Railroads in a Backward Economy: The Case of Mexico. The Journal of Economic History 39(4): 939-960. https://www.jstor.org/stable/2120337

Cournède, B., and O. Denk (2015). Finance and Economic Growth in OECD and G20 Countries. OECD Economics Department Working Papers, No. 1223, OECD Publishing, Paris. https://doi.org/10.1787/5js04v8z0m38-en

Demetriades, P.A, and T. Mamuneas (2000). Intertemporal Output and Employment Effects of Public Infrastructure Capital: Evidence from 12 OECD Economies. The Economic Journal 110(465): 687-712. https://www.jstor.org/stable/2565922

Easterly, W., and S. Rebelo (1993). Fiscal Policy and Economic Growth: An Empirical Investigation. Journal of Monetary Economics 32(3): 417-458.

https://ideas.repec.org/a/eee/moneco/v32y1993i3p417-458.html

Feltenstein, A., and J. Ha (1995). The Role of Infrastructure in Mexican Economic Reform. The World Bank Economic Review 9(2): 287-304. https://www.jstor.org/stable/3989921?seq=1

Fernald, J. (1999). Roads to Prosperity? Assessing the Link between Public Capital and Productivity. The American Economic Review 89(3): 619-638. https://www.aeaweb.org/articles?id=10.1257/aer.89.3.619 
Fournier, J.M., (2016). The Positive Effect of Public Investment on Potential Growth. OECD Economic Department Working Papers, No. 1347, OECD Publishing. https://doi.org/10.1787/15e400d4-en

Geweke, J., and S. Porter-Hudak (1983). The Estimation and Application of Long Memory Time Series Models. Journal of Time Series Analysis 4(4): 221-238. https://onlinelibrary.wiley.com/doi/abs/10.1111/j.1467-9892.1983.tb00371.x

González, M. de los A. (2002). Do Changes in Democracy Affect the Political Budget Cycle? Evidence from Mexico. Review of Development Economics 6(2): 204-224. https://onlinelibrary.wiley.com/doi/abs/10.1111/1467-9361.00150

Guajardo, G., Salas, F., and D. Velázquez (2010). Energía, Infraestructura y Crecimiento, 1930-2008. In Kuntz, S. (2010), Historia Económica General de México. De la Colonia a Nuestros Días, El Colegio de México/Secretaría de Economía.

Ilzetzki, E., Mendoza, E.G., and C.A. Végh, C. (2013). How Big (Small?) are Fiscal Multipliers? Journal of Monetary Economics 60(2): 231-254.

https://www.sciencedirect.com/science/article/abs/pii/S030439321200116X

Johansen, S (1988). Statistical Analysis of Cointegration Vectors. Journal of Economics Dynamic and Control 12(2-3): 231-254. https://www.sciencedirect.com/science/article/pii/0165188988900413

Johansen, S., and K. Juselius (1990). Maximun Likelihood Estimation with Inference on Cointegration with Applications to the Demand for Money. Oxford Bulletin of Economics and Statistics 52(2): 169-210. https://onlinelibrary.wiley.com/doi/abs/10.1111/j.1468-0084.1990.mp52002003.x

Johansen, S. (2005). Interpretation of Cointegrating Coefficients in the Cointegrated Vector Autoregressive Model. Oxford Bulletin of Economics and Statistics 67(1): 93-104. https://onlinelibrary.wiley.com/doi/abs/10.1111/j.1468-0084.2005.00111.x

Lachler, U., and D.A. Aschauer (1998). Public Investment and Economic Growth in Mexico. Policy Research Working Paper No. 1964, The World Bank. https://econpapers.repec.org/paper/wbkwbrwps/1964.htm

Munnell, A.H. (1992). Policy Watch. Journal of Economic Perspectives 6(4): 189-198. https://www.aeaweb.org/articles?id=10.1257/jep.6.4.189

Nazmi, N., and M. Ramirez (1997). Public and Private Investment and Economic Growth in Mexico. Contemporary Economic Policy 15(1): 65-75. https://onlinelibrary.wiley.com/doi/abs/10.1111/j.1465-7287.1997.tb00455.x

Noriega, A., and M. Fontenla (2007). La Infraestructura y el Crecimiento Económico en México. El Trimestre Económico 74(296): 885-900. http://www.eltrimestreeconomico.com.mx/index.php/te/article/view/386/583

Ramirez, M. (1994). Public and Private Investment in Mexico, 1950-90: An Empirical Analysis. Southern Economic Journal 61(1), 1-17. https://www.jstor.org/stable/1060126

Ramirez, M. (1996). Public and Private Investment in Mexico and Chile: An Empirical Test of the Complementarity Hypothesis. Atlantic Economic Journal 24(4): 301-320. https://link.springer.com/article/10.1007/BF02298433 
Ramirez, M., and N. Nazmi (2003). Public Investment and Economic Growth in Latin America: An Empirical Test. Review of Development Economies 7(1): 115-126. https://onlinelibrary.wiley.com/doi/abs/10.1111/1467-9361.00179

Shimotsu, A. and P.C.B Phillips (2005). Exact Local Whittle Estimation of Fractional Integration. The Annals of Statistic 33(4): 1890-1993. https://projecteuclid.org/euclid.aos/1123250232

Solís, L. (1999). Evolución de la Economía Mexicana. El Colegio Nacional.

Ventosa-Santaulària, D., and M. Gómez-Zaldívar (2010). Testing for a Deterministic Trend when there is Evidence of Unit Root. Journal of Time Series Econometrics 2(2): 1-26. https://www.degruyter.com/view/j/jtse.2011.2.2/jtse.2011.2.2.1013/jtse.2011.2.2.1013.xml

Warner, A.M. (2014). Public Investment as an Engine of Growth. IMF Working Paper,No.14/148. International Monetary Fund. https://www.imf.org/external/pubs/ft/wp/2014/wp14148.pdf 


\section{Appendix 1: Detection of structural breaks}

The results in Table A1 contain three test statistics associated with the Bai and Perron (1998, 2003) procedure applied to the first difference of the series (this procedure can only be applied to stationary data). These tests show conclusive evidence of a structural break for GDP only, for which all three test statistics concur not only in finding a break but also on the date when this occurs, i.e., 1934. Evidence of structural change is weaker for the total public investment and agricultural expenditure series, since we ultimately use the sequential test (as recommended by Bai and Perron, 2003, themselves) to infer results. In neither of these two series does the sequential test provide any evidence of a structural break.

The only case where the Bai and Perron test shows convincing evidence of a structural break is the GDP series (in 1943). In no other case does the sequential test yield sufficient evidence to reject the null hypothesis of no break. Therefore, we believe that a better strategy is to proceed with a standard cointegration analysis, making sure that the short-run equations satisfy the assumptions of independence, homoscedasticity, and normality.

Table A1: Results of the Bai and Perron test.

\begin{tabular}{|c|c|c|c|c|c|}
\hline \multirow[b]{2}{*}{ Variable } & \multicolumn{3}{|c|}{ Sequential test } & \multirow{2}{*}{$\begin{array}{l}\text { UD MAX } \\
\text { (Date) }\end{array}$} & \multirow{2}{*}{$\begin{array}{l}\text { WD MAX } \\
\text { (Date) }\end{array}$} \\
\hline & \multicolumn{2}{|c|}{ Test statistic } & Date & & \\
\hline \multirow{2}{*}{ GDP } & 0 vs 1 & $42.575 * * *$ & \multirow{2}{*}{1943} & $42.575^{* * *}$ & $42.575^{* * *}$ \\
\hline & 1 vs 2 & 3.585 & & (1934) & (1934) \\
\hline \multirow{2}{*}{ Private investment } & \multirow{2}{*}{0 vs 1} & \multirow{2}{*}{1.470} & \multirow{2}{*}{-} & 1.473 & 2.035 \\
\hline & & & & - & - \\
\hline Total & & & & $8.951 * *$ & $13.755^{* *}$ \\
\hline investment & 0 vs 1 & 4.089 & - & $(1934,1972)$ & $\begin{array}{c}(1934,1943,1956, \\
1956,1972)\end{array}$ \\
\hline \multirow{2}{*}{ Social development } & \multirow{2}{*}{0 vs 1} & \multirow{2}{*}{0.744} & \multirow{2}{*}{-} & 1.707 & 2.215 \\
\hline & & & & - & - \\
\hline Industrial & \multirow{2}{*}{0 vs 1} & \multirow{2}{*}{2.740} & \multirow{2}{*}{-} & 3.124 & 4.961 \\
\hline development & & & & - & - \\
\hline \multirow{2}{*}{$\begin{array}{l}\text { Transport and } \\
\text { communications }\end{array}$} & \multirow{2}{*}{0 vs 1} & \multirow{2}{*}{1.509} & \multirow{2}{*}{ - } & 1.751 & 4.383 \\
\hline & & & & - & - \\
\hline \multirow{2}{*}{$\begin{array}{l}\text { Agricultural } \\
\text { development }\end{array}$} & \multirow[b]{2}{*}{0 vs 1} & \multirow[b]{2}{*}{3.847} & \multirow[b]{2}{*}{ - } & $7.491^{*}$ & $14.752^{* * *}$ \\
\hline & & & & $\begin{array}{c}(1935,1950, \\
1961)\end{array}$ & $\begin{array}{c}(1935,1950,1958, \\
1966,1974)\end{array}$ \\
\hline \multirow{2}{*}{$\begin{array}{l}\text { Government } \\
\text { administration }\end{array}$} & \multirow{2}{*}{0 vs 1} & \multirow{2}{*}{1.156} & \multirow{2}{*}{ - } & 1.283 & 2.049 \\
\hline & & & & - & - \\
\hline
\end{tabular}

$\S$ The maximum number of lags was determined by $L_{\max }=\left[12(T / 100)^{1 / 4}\right]$. The distribution of errors may vary between subsamples. The symbols ${ }^{* * *}, * *$ and $*$ denote rejection of the null at the 1,5 , and 10 percent level, respectively. 
From Table A2, we infer the following: i) setting a confidence level at 5\%, all short-run equations satisfy the normality, independence, and homoscedasticity assumptions (except in the case of total public investment, for which Equation 2 shows no evidence of heteroscedasticity); ii) in all cases, there is at least one significant error correction mechanism, which implies additional evidence of cointegration, and; iii) only for private investment is there any systematic evidence that it can be considered weakly exogenous. GDP, meanwhile, is always affected by disequilibrium and therefore cannot be considered weakly exogenous. Public investment in social development, agricultural development, and industrial development is not weakly exogenous, whereas total public investment and public investment in transport and communications and government administration are. 


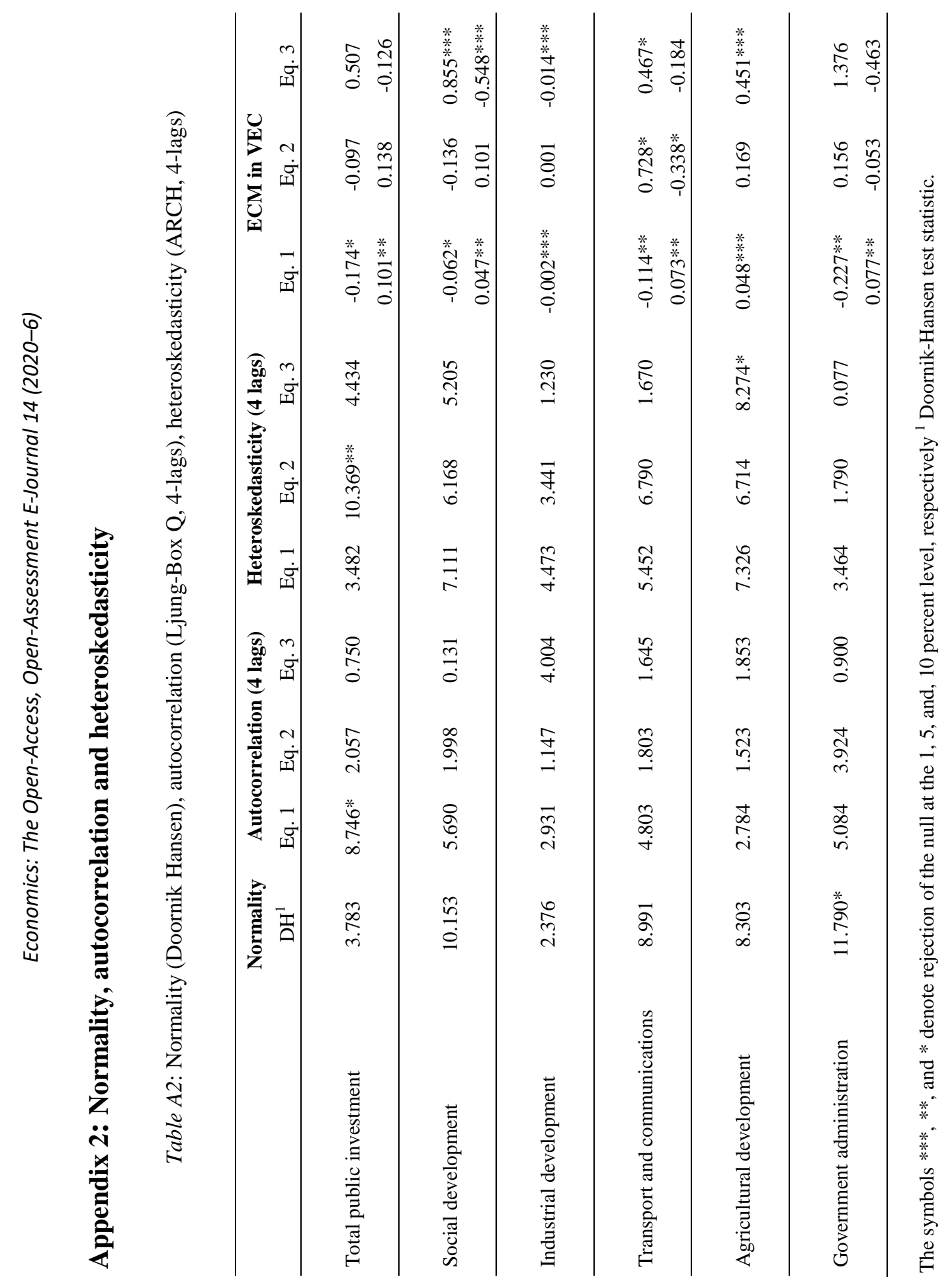

